\title{
The fish fauna in the fish passage at the Ourinhos Dam, Paranapanema River
}

\author{
Marlene Sofia Arcifa and André Luiz Henríques Esguícero
}

\begin{abstract}
The composition and abundance of the fish assemblage were evaluated in the fish ladder of Ourinhos Dam, the newest dam (closed in 2005) in the cascade of dams constructed on the Paranapanema River. Samplings were carried out three times on a diel cycle, in three sampling periods, two in the warm season and one in the cold season of $2008-2009$. The ladder was closed and emptied and the entire fish assemblage was sampled and identified. Most individuals were released alive downstream of the dam. The assemblage found in the ladder was compared with the fish fauna sampled in the reservoir and in downstream sites, in the same period. Twenty seven species and a total of 4682 individuals were caught in the ladder. Pimelodus maculatus was the only migratory species, which was caught in low number in the ladder $(0.04 \%$ of the total captured), where small sedentary species predominated. The most abundant species were the non-migratory Apareiodon affinis, Bryconamericus stramineus, Astyanax fasciatus and Parodon nasus. Individuals observed in the ladder's window were moving up- and down the passage. The fish ladder is a microhabitat inhabited by an abundant association of benthic organisms that is probably used as a food resource for the fish assemblage in the ladder. The similarity between the fish fauna in the ladder and that of the Ourinhos Reservoir was low (26\%). The species richness of migrants in the stretch between the uspstream reservoir (Chavantes) and the downstream one (Salto Grande), before the Ourinhos dam closure (23 species) was reduced to 16 and 12 species in Salto Grande and Ourinhos reservoirs, respectively, after the dam closure, and to a single species in the ladder.
\end{abstract}

A composição e abundância da ictiofauna da escada de peixes da barragem de Ourinhos, a mais nova hidrelétrica (fechada em 2005) na sequência de barragens construídas no rio Paranapanema, foram avaliadas três vezes em um ciclo diário, em três períodos de coleta, dois no verão e um no inverno de 2008-2009. A escada foi fechada e esvaziada e os peixes coletados e identificados, antes da devolução da maior parte deles a jusante. A ictiofauna da escada foi comparada à do reservatório de Ourinhos, coletada na mesma época. Vinte e sete espécies e 4862 indivíduos foram coletados na escada. Pimelodus maculatus foi a única espécie migradora coletada, mas em número baixo na escada, onde predominaram espécies sedentárias pequenas. As espécies mais abundantes foram as sedentárias Apareiodon affinis, Bryconamericus stramineus, Astyanax fasciatus e Parodon nasus. Observações feitas na janela da escada revelaram que os peixes realizavam movimentos ascendentes e descendentes. A escada de peixes é um microhabitat habitado por uma abundante associação de organismos bentônicos que é provavelmente usada como recurso alimentar pela ictiofauna na escada. A similaridade entre a ictiofauna no reservatório de Ourinhos e na escada é baixa (26\%). A riqueza de espécies migradoras no trecho entre os reservatórios a montante (Chavantes) e a jusante (Salto Grande), antes do fechamento da barragem de Ourinhos (23 espécies) foi reduzida para 16 e 12 espécies, respectivamente em Salto Grande e Ourinhos, depois do fechamento da barragem, e a apenas uma espécie na escada.

Key words: Fish abundance, Fish fauna composition, Fish ladder, South America.

\section{Introduction}

Most medium and large rivers in Brazil are impounded by hydroelectric dams, nowadays totaling at least 598 in operation (ANEEL, 2012). The negative effects of dams are more evident on fish species that perform upstream migration purposing spawning, once dams block their migration routes (Agostinho et al., 2007a). In addition, dams control floods on the impounded river (Agostinho et al., 2004), which influences the extension of growth and feeding sites (Sanches et al., 2006).

One of the mitigation policies of this scenario is to construct fish passages, specially fish ladders (Agostinho et

Universidade de São Paulo, Departamento de Biologia, Av. Bandeirantes 3900, 14040-901 Ribeirão Preto, SP, Brazil. marcifa@usp.br(MAS); andre.esguicero@gmail.com(ALHE) 
al., 2007a). However, for Neotropical fish populations, ladders are criticized for having low efficiencies in facilitating the exchanges between the up- and downstream stretch of rivers (Agostinho et al., 2007b; Agostinho et al., 2007c). The inefficiency of most fish passages for the descending movement of adults and early life stages of fish is an issue of much concern lately (Agostinho et al., 2007b), as well as the selectivity for the entrance and ascending movements of individuals (Agostinho et al., 2007c). The low gene flow caused by the loss of connectivity due to a river impoundment can lead to differences among populations of the same species on the long-term (Esguícero \& Arcifa, 2010). Alternative routes for migration, such as tributaries, adequate free-flowing sections of the river, and suitable growth and feeding sites are important requisites for maintaining the population of a migratory species after the impoundment (Esguícero \& Arcifa, 2010).

Cascade of dams has been constructed on the main rivers of southeastern Brazil, such as Tietê, Grande, and Paranapanema. A sequence of dams is more drastic in cutting the connection up- and downstream of the dam for the whole fish fauna, not only for preventing the gene flow but for impairing the access to suitable spawning and feeding grounds. Particularly for long distance migratory fish, the shortening of free-flowing sections of the river may cause local extinctions (Agostinho et al., 2007a). In the case a fish passage is installed, suitable spawning sites and nursery grounds are not always available up- and downstream of the dam (Pompeu et al., 2012). An extreme condition imposed by impoundments is driven by the absence of spawning and nursery sites up- and downstream the dam, common in rivers with dams constructed in sequence, in which case a fish passage is not necessary (Pompeu et al., 2012). Therefore, some fish passages may be an ecological trap for ascending fish and leading them to a stretch devoid of suitable spawning sites (Pelicice \& Agostinho, 2008).

The aim of this study was to evaluate the use of the fish ladder of the Ourinhos Dam by the fish fauna. The dam is located on the Paranapanema River, which is situated between two other dams closed 40 - 50 years ago and devoid of fish passages. The study was driven by the questions: Is the fish ladder efficient for maintaining the connection between stretches up- and downstream of the dam, particularly for long distance migratory species? Does this recent impoundment influence the fish assemblage composition of the stretch between two older dams, up- and downstream of the Ourinhos Dam?

\section{Material and Methods}

\section{Study area}

Paranapanema River is an important tributary of the upper Paraná River, whose headwaters are located in the Serra of Paranapiacaba, in São Paulo State. After running ca. $920 \mathrm{~km}$ and receiving its main tributaries, Itararé, Pardo, Tibagi, and Pirapó rivers (Ziesler \& Ardizzone, 1979; Castro et al., 2003), it flows into the left margin of the Paraná River (Fig. 1).

A sequence of eleven dams has been constructed on the Paranapanema River and the oldest one is the Paranapanema Dam, which was closed in 1936 (Fig. 1). Ourinhos Dam, the newest one closed in 2005, has a fish ladder (Fig. 2) and is located between the reservoirs of Salto Grande, downstream,

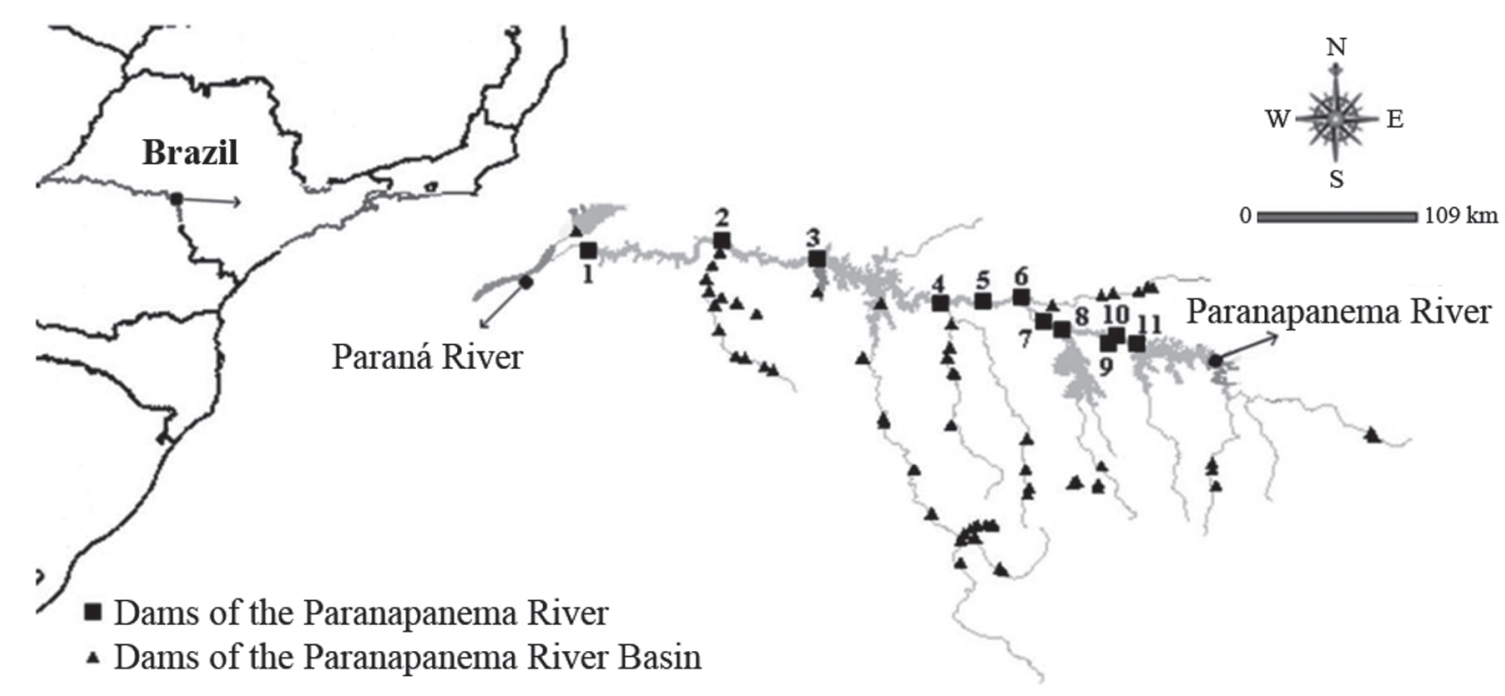

Fig 1. Location of Paranapanema River in Brazil. In detail on the right the sequence of 11 dams constructed on the river (ANEEL 2012): 1- Rosana, 2 - Taquaruçu, 3 - Capivara, 4 - Canoas I, 5 - Canoas II, 6 - Salto Grande, 7 - Ourinhos, 8 - Chavantes, 9 - Paranapanema, 10 - Piraju, and 11 - Jurumirim. Other dams in tributaries are shown as triangles. 
and Chavantes upstream, closed respectively in 1958 and 1970 (Duke Energy, 2008). The last two do not have fish passages.

Ourinhos Reservoir is a "run-of-the-river" type, with a small area $\left(\sim 5 \mathrm{~km}^{2}\right)$ and a retention time of $c a$. 1 day. The river stretch of $c a .15 \mathrm{~km}$ where Ourinhos Reservoir is located does not have large tributaries but two medium-sized ones, Anhumas and Claro streams, in addition to seven small streams and creeks. The original stretch of the river, occupied now by the reservoir, presented rocky bottom, without marginal lakes and floodplain. After the closure of the dam two artificial ponds were formed and one is connected with the reservoir. Dowstream and not far from the dam there are marginal lakes and a floodplain, in the area of the Salto Grande Reservoir.

The fish ladder is a pool and weir type with orifices at the bottom, $386 \mathrm{~m}$ long, with two glass windows $(1.5 \times 1.0 \mathrm{~m})$ on one side at the upper part of the ladder, and a water velocity of $1.2-2.5 \mathrm{~m} \cdot \mathrm{s}^{-1}$.

\section{Sampling of the fishfauna in the ladder}

Samplings were carried out in the warm-wet season (November 2008 and January 2009) and in the cold-dry season (July 2009), three times during $24 \mathrm{~h}$. Samplings were always carried out in the following sequence: morning $(8-10 \mathrm{~h})$, afternoon (16 - $18 \mathrm{~h})$ and early next morning $(8-10 \mathrm{~h})$. This procedure purposed to evaluate the occupation of the ladder by the species in different periods of the day. The ladder operation was not allowed after dark, and, consequently, the ladder was not sampled at night.

The fish assemblage in the fish ladder was numerically evaluated by sampling the individuals in the ladder after gradual reduction of the water flow and closing of the pools (Fig. 3). Gears used were a seining net ( $5 \mathrm{~mm}$ between adjacent knots, $10 \mathrm{~m}$ long) and a rectangular sieve $(1.0 \times 0.7 \mathrm{~m}, 5 \mathrm{~mm}$ between adjacent knots). Observations were also made at the two windows mentioned above, during $1 \mathrm{~h}$ in each sampling occasion, for obtaining information on fish species and the direction they were moving.

After identification and counting the individuals, most of them were released alive to the downstream area, and a small sample was taken and fixed with $10 \%$ formalin. In the laboratory, they were transferred to $70 \%$ ethanol and measured. Juveniles and adults were separated by their size.

The similarity coefficient of Jaccard $(\mathrm{Sj})$ was used for comparing the assemblage in the ladder and the fish fauna in Ourinhos: where $\mathrm{Sj}=\mathrm{c} /(\mathrm{a}+\mathrm{b}-\mathrm{c}), \mathrm{a}=$ species found in the local $\mathrm{a}, \mathrm{b}=$ species found in the local $\mathrm{b}, \mathrm{c}=$ species found in both local a and b (Margalef, 1974).

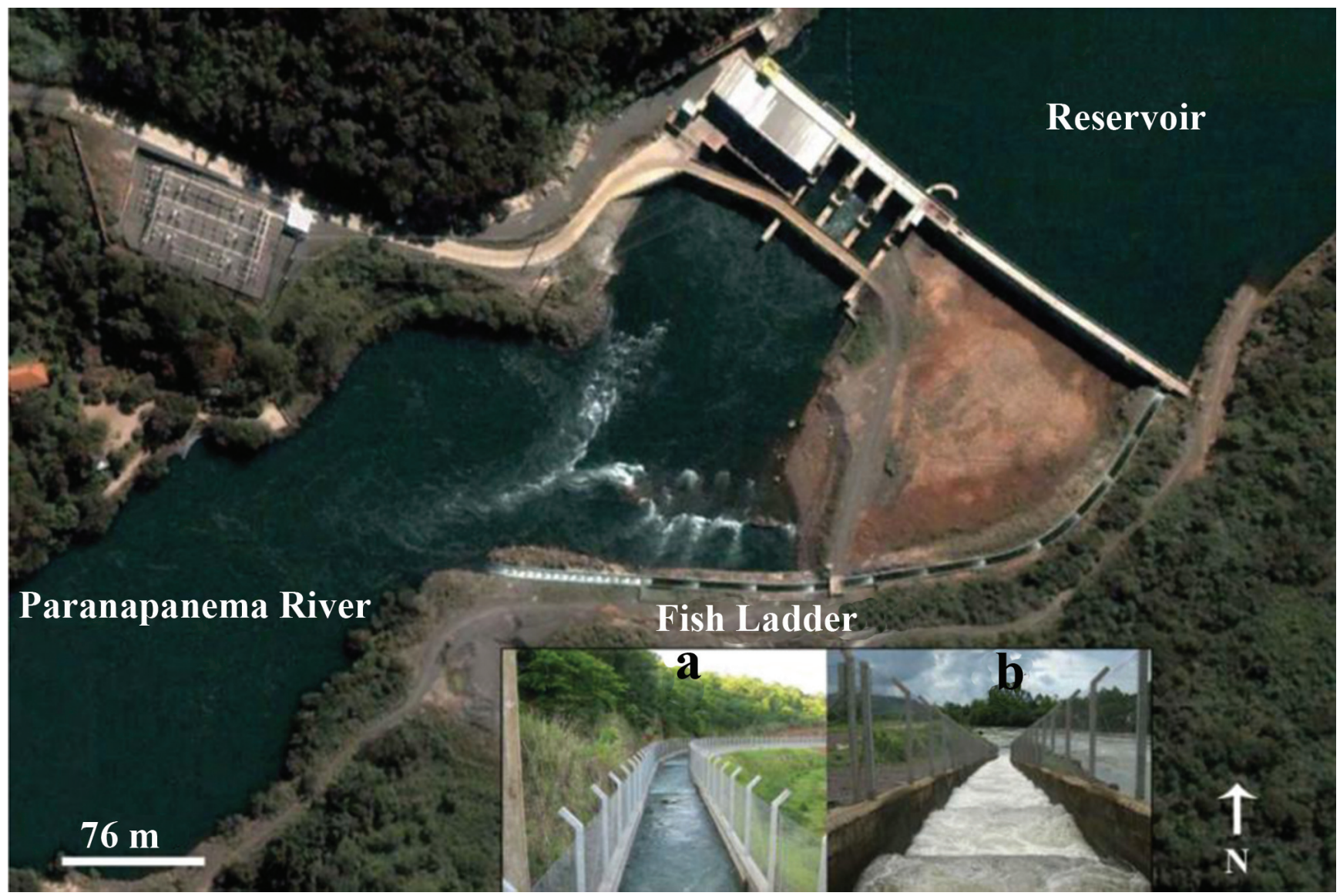

Fig. 2. The fish ladder of Ourinhos Dam. a) the middle stretch and b) the ladder's flow into the river. 


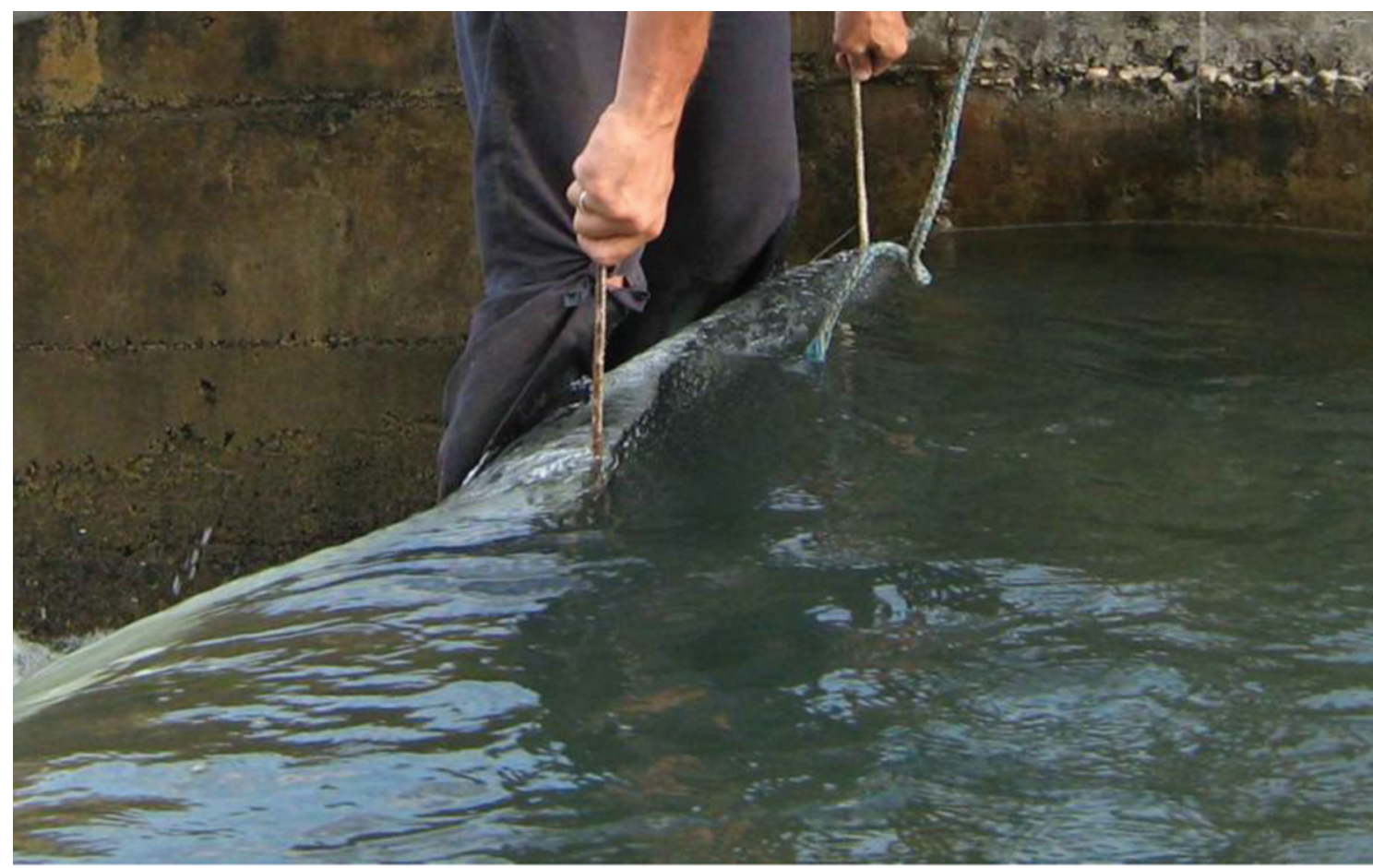

Fig. 3. Closing the pool for the emptying operation.

\section{Sampling of the local fishfauna}

The fish fauna of the Ourinhos Reservoir was sampled at 21 stations (two of them located downstream of the dam) using the following sampling gears: a rectangular sieve $(1.0 \mathrm{x}$ $0.7 \mathrm{~m}, 5 \mathrm{~mm}$ between adjacent knots), a seining net ( $5 \mathrm{~mm}$ between adjacent knots, $10 \mathrm{~m}$ long), cast nets ( 15 to $40 \mathrm{~mm}$ mesh net, 2 to $4 \mathrm{~m}$ in diameter), and gill nets (15 to $60 \mathrm{~mm}$ between adjacent knots, $10 \mathrm{~m}$ long, $1.5 \mathrm{~m}$ high).

Samplings were carried out during the warm-wet season (10 days in November 2008, 9 days in January 2009) and the cold-dry season (9 days in July 2009). Gill nets were set for 24 $\mathrm{h}$, being checked every $12 \mathrm{~h}$, in each station. Individuals caught were fixed in the field with $10 \%$ formalin and transferred to $70 \%$ ethanol in the laboratory.

Some individuals were deposited at the Laboratório de Ictiologia de Ribeirão Preto do Departamento de Biologia, Faculdade de Filosofia, Ciências e Letras de Ribeirão Preto, Universidade de São Paulo, under the identification number LIRP 8926 to 8948.

\section{Results}

A total of 4682 individuals (2017 and 1554 in November 2008 and January 2009, respectively, warm season; 1111, July 2009 - cold season) of twenty seven species was caught in the fish ladder (Table 1). We noticed that the ladder was repopulated after the normal operation was restablished, inclusive during the night, because individuals were caught there in the morning. We do not know whether some individuals returned to the ladder after released or they were new individuals. Most species in the ladder were small-sized sedentary and only one long distance migratory species Pimelodus maculatus (Table 2), but in low abundance (two individuals; $0.04 \%$ of the total). Four species were ranked as the most abundant and frequent in the ladder - Apareiodon affinis, Bryconamericus stramineus, Astyanax fasciatus, and Parodon nasus (Fig. 4, Table 2), which comprised $79 \%$ of the total number of individuals. The species grouped as "Others", which contributed with $7.4 \%$ were: Astyanax altiparanae, $A$. bockmanni, A. paranae, Cichla ocellaris, C. temensis, Geophagus brasiliensis, Hypostomus cf. margaritifer, Hypostomus sp. 1, Hypostomus sp. 2, Hypostomus sp. 4, Leporinus amblyrhynchus, Leporinus octofasciatus, Loricaria prolixa, Megalancistrus aculeatus, Pimelodella aff. gracilis, Pimelodus maculatus, and Tatia neivai. Overall, juveniles predominated in the ladder. The similarity coefficient for the fish fauna in the ladder and Ourinhos Reservoir was $26 \%$.

Piscivorous fish were rare in the ladder; only five young Cichla ocellaris and C. temensis were caught during all the sampling periods. Piscivorous species represented $9 \%$ of the total captured upstream of the dam, and $6 \%$ of the individuals caught downstream of the dam. Acestrorhynchus lacustris, Cichla ocellaris, C. temensis, Galeocharax knerii, Hoplias malabaricus, Plagioscion squamosissimus, Salminus hilarii, and Serrasalmus maculatus were the piscivorous representatives.

The observations made at the window of the ladder revealed that the individuals were moving up and down the passage and did not perform an exclusive unidirecional 
Table 1. Taxonomic list of the fish caught in Ourinhos Dam in 2008-2009. • Species caught only downstream from the dam. * Species caught in the fish ladder.

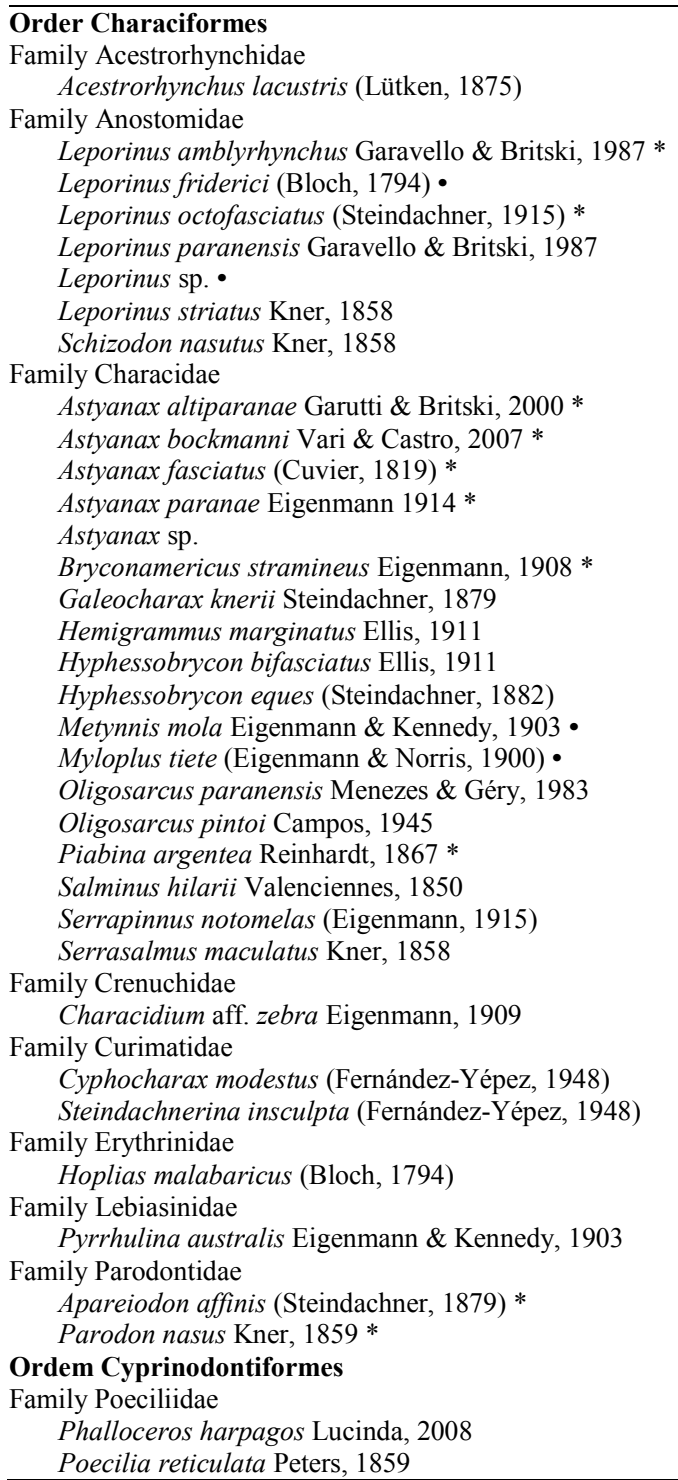

ascending or descending movement. The same dominant species sampled in the ladder were observed through the windows.

\section{Discussion}

The fish ladder of the Ourinhos Dam, as several others in Brazilian dams, was constructed with the purpose to maintain the connection of downstream-upstream stretches isolated by the impoundment, particularly for long distance migratory fish species. However, sedentary species dominated in the Ourinhos' ladder and the contribution of migratory species to the fish assemblage was reduced to one species, $P$. maculatus, which is in accordance to the data of four previous sampling periods carried out in 2006-2007 (J. C. Garavello, unpublished data). Downstream of the Ourinhos Dam, in Salto

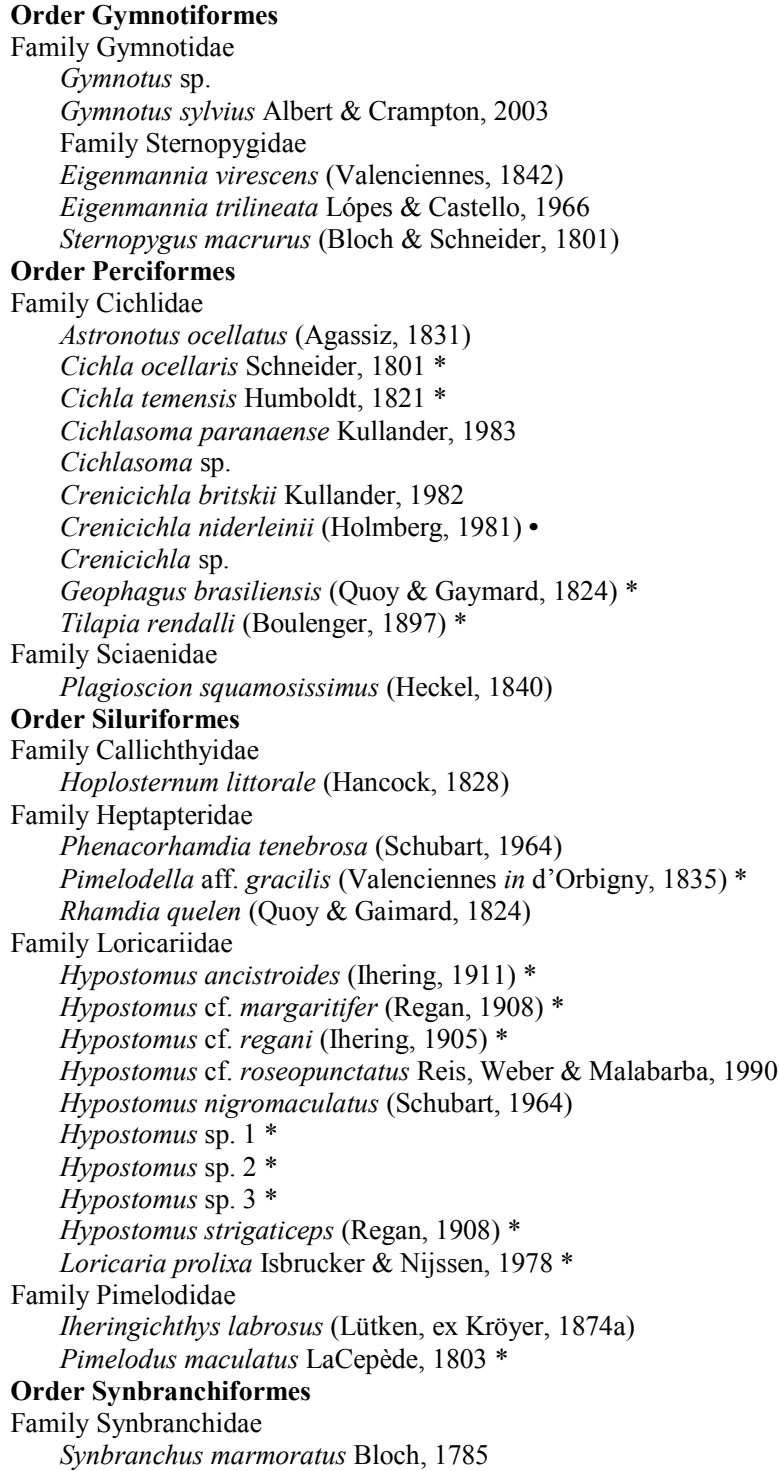

Grande, sixteen migratory species were recorded in contrast with the one in the Ourinhos' ladder.

The paucity of migratory species in the fish ladder might be explained in several ways: in the lower part of the ladder the flow is lower than in some areas in the river channel (see Fig. 2) and it appears unable to attract most migrants; in the downstream reservoir, Salto Grande, the dominant species are mostly small and medium-sized sedentary species, such as Acestrorhynchus lacustris, Astyanax altiparanae, and Steindachnerina insculpta (Brandão et al., 2009); and the spatial distribution of the species might also influence their access to the ladder.

In this study we have not evaluated the spatial distribution of the species, but in other stretches of the Paranapanema basin, this aspect has been already studied. In the Tibagi River, a large tributary of the lower Paranapanema River, 
Table 2. Index of Frequency (\%) and size for the species caught in the fish ladder in the samplings. Source: 1. Reis et al. (2003); * long distance migratory species.

\begin{tabular}{lccc}
\hline \multicolumn{1}{c}{ Species } & $\%$ & Size & Vouchers \\
\hline Apareiodon affinis & 29.00 & small & LIRP8931 \\
Astyanax altiparanae & 1.41 & small & LIRP8937 \\
Astyanax bockmanni & 0.13 & small & \\
Astyanax fasciatus & 18.74 & small & LIRP8948 \\
Astyanax paranae & 0.04 & small & \\
Bryconamericus stramineus & 22.67 & small & LIRP8935 \\
Cichla ocellaris & 0.04 & medium & \\
Cichla temensis & 0.06 & medium & \\
Geophagus brasiliensis & 0.04 & medium & \\
Hypostomus ancistroides & 3.50 & small & \\
Hypostomus cf. margaritifer & 0.13 & small & \\
Hypostomus regani & 1.94 & medium & \\
Hypostomus sp. 1 & 0.77 & small & LIRP8945 \\
Hypostomus sp. 2 & 0.26 & small & LIRP8929 \\
Hypostomus sp. 3 & 2.01 & small & LIRP8933 \\
Hypostomus sp. 4 & 1.97 & small & LIRP8934 \\
Hypostomus strigaticeps & 0.02 & small & \\
Leporinus amblyrhynchus & 1.69 & small & LIRP8938 \\
Leporinus octofasciatus & 1.07 & small & LIRP8940 \\
Loricaria prolixa & 0.04 & small & LIRP8944 \\
Megalancistrus aculeatus & 0.02 & small & \\
Parodon nasus & 8.55 & small & LIRP8930 \\
Piabina argentea & 3.74 & small & LIRP8939 \\
Pimelodella aff. gracilis & 0.04 & small & \\
Pimelodus maculatus $*$ & 0.04 & medium & LIRP8943 \\
Tatia neivai & 0.28 & small & LIRP8928 \\
Tilapia rendalli & 2.80 & medium & \\
\hline
\end{tabular}

migratory species, such as Leporinus friderici, L. obtusidens, and Pimelodus maculatus, which also occur in Ourinhos and Salto Grande reservoirs, were distributed near the bottom of the pelagic zone, whereas Astyanax altiparanae (not a long distance migratory species) occupied the upper layer of the littoral (Bennemann et al., 2000). Supposing that the same behavior is maintained downstream of the Ourinhos Dam, some of the migratory species of Salto Grande may swim near the bottom, and would not reach the entrance of the ladder at the Ourinhos Dam near the margin. In addition, the currents in the river channel could be more attractive for those species.

The access to both the exit and the entrance of the ladder is suitable for species preponderantly distributed onshore. Several papers report that the fish fauna in Brazilian reservoirs occupy more effectively the littoral zone than the limnetic zone (Arcifa et al., 1988; Arcifa \& Meschiatti, 1993; review by Araújo-Lima et al., 1995; review by Arcifa \& Northcote, 1997; Meschiatti \& Arcifa, 2002).

It is possible that the species in the ladder are from the Ourinhos and Salto Grande reservoirs. A few species found in the ladder have not been lately recorded in Salto Grande (Vianna, 2008; Brandão et al., 2009), such as Bryconamericus stramineus, Cichla ocellaris, and Pimelodella aff. gracilis, suggesting they were from the Ourinhos Reservoir. However, we should consider the possibility that the sampling methods used by those authors have influenced the species composition. Although descending displacement is considered rare in fish passages, particularly for migratory species (Agostinho et al., 2007b; Agostinho et al., 2011), Makrakis et al. (2007) report a bidirectional movement of a larger number of small-sized non-migratory species, and of four out of seven migratory species.

Predators can be present in the ladder, probably attracted by forage species (Makrakis et al., 2007). In the ladder of Ourinhos, predation was low or absent, as only juveniles of two species, Cichla temensis and C. ocellaris, were present among the eight found in the fish assemblage of the study area. Moreover, juveniles of C. ocellaris could have been searching for food in the ladder, other than fish. Dietary items of young Cichla differ from those of adults, encompassing

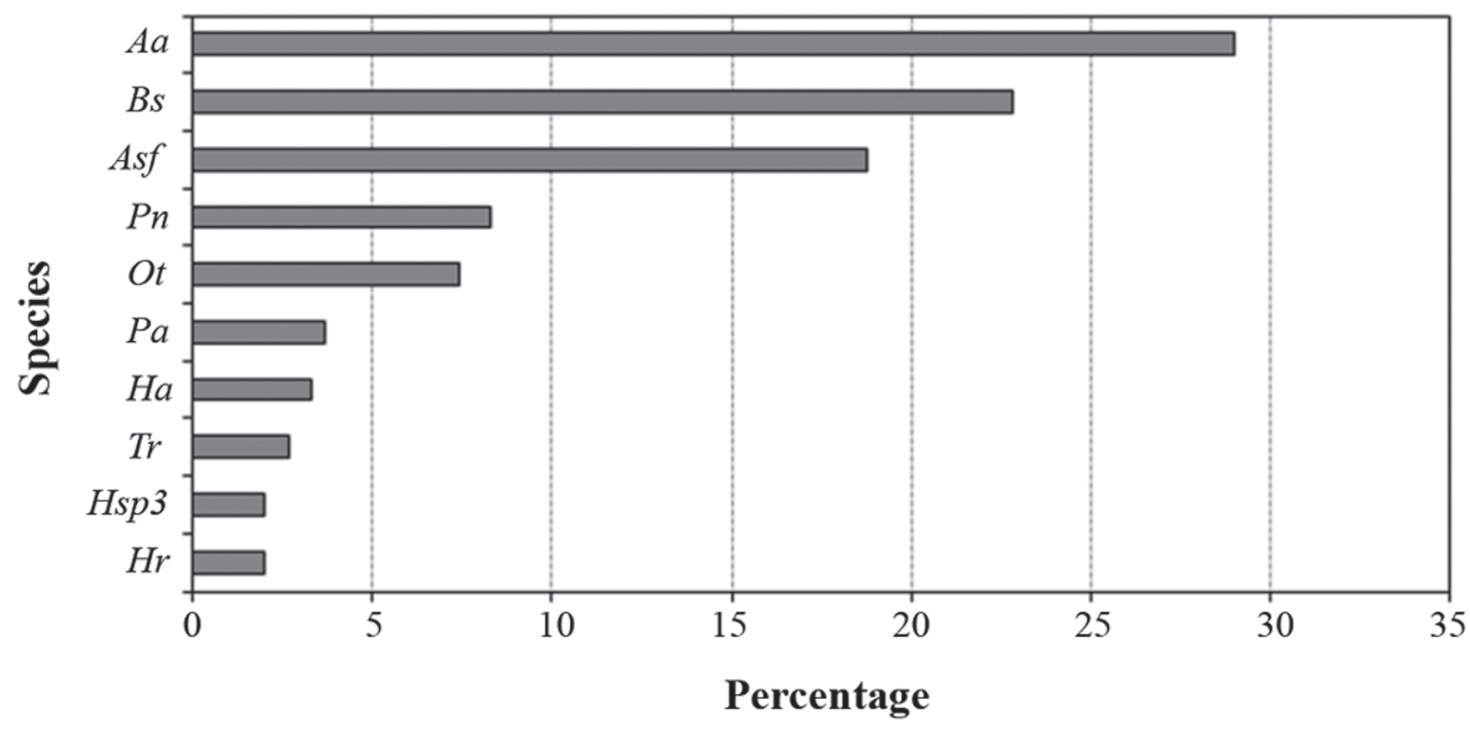

Fig. 4. Relative abundance of species in the fish ladder. Abbreviations: Aa-Apareiodon affinis; Bs-Bryconamericus stramineus; Asf-Astyanax fasciatus; Pn-Parodon nasus; Ot - others; Pa-Piabina argentea; Ha - Hypostomus ancistroides; Tr-Tilapia rendalli; Hsp3 - Hypostomus sp. 3; Hr-Hypostomus cf. regani. 
immature insects, such as larvae of the dipteran chaoborid and mayfly nymphs (Arcifa \& Meschiatti, 1993). Food resources in the study ladder are high enough to attract several fish species (A. L. H. Esguícero, personal observation), which may find a suitable feeding site and a refuge from predators.

A dataset originated from several surveys in this river stretch (Dias \& Garavello, 1998; Dias 2003; Vianna 2008; Brandão et al. 2009; CBA, unpublished data; Souto 2011; data from Biota/Fapesp and the data of this study) show that the species richness in Salto Grande is much higher than in the Ourinhos' ladder. The number of species was 82 in the stretch between Salto Grande (downstream) and Chavantes (upstream) reservoirs, after the closure of Ourinhos Dam, 79 in the Ourinhos Reservoir, and 27 in the Ourinhos' ladder. The number of migratory fish decreased from 23 species, in the stretch between Chavantes and Salto Grande, before the construction of Ourinhos Dam, to 16 species in Salto Grande, after the closure of Ourinhos Dam, to 12 species in the Ourinhos Reservoir, and just one species in the ladder.

The Ourinhos project would fit in the type B (Fig. 2 in Pompeu et al., 2012), where natural spawning sites and nurseries are located only downstream of the dam. Therefore, we may hypothesize that before the construction of the Ourinhos Dam, two situations might be depicted for migratory species: they would spawn and grow in suitable habitats located within the area of the downstream reservoir, Salto Grande, or spawn in the free-flowing stretch near the upstream dam, Chavantes, the eggs were developing while drifting downward until reaching the nursery grounds in Salto Grande. However, with the construction of the Ourinhos Dam, the ichthyofauna was confined to a stretch of $c a$. $15 \mathrm{~km}$, between two other dams (Chavantes and Salto Grande) devoid of fish passages for four decades. As the short stretch occupied by the Ourinhos Reservoir does not receive large tributaries, alternative routes for reproductive migration are unavailable. Large tributaries can be very important for the reproduction of fish species after the blockage of migratory displacements, as found in the Paraná River (Antonio et al., 2007) and other stretches of Paranapanema River (Hoffmann et al., 2005; Vianna \& Nogueira, 2008). More adequate alternative routes can be found in the Salto Grande Reservoir, which receives at least two large tributaries (Pardo and Novo rivers).

The Ourinhos' fish ladder favors mainly the exchange of sedentary species, which were not the main target during its planning. The ladder may be even a feeding site for some or most of them as the steps and walls of the ladder provide a substrate for an abundant association of benthic organisms. As these fish species are pre-adapted to lentic environments, they will not be threatened by the unsuitable spawning and growing conditions upstream of the dam. Therefore, individuals of sedentary species that ascend the ladder would not be impaired by ecological conditions upstream of the dam, and the gene flow of part of the fish fauna is maintained. Therefore, the fish ladder studied should not be constructed because its main purpose is to connect upstream and downstream stretches to allow migratory species fulfill their life cycles.

\section{Acknowledgments}

We thank T. N. A. Pereira for help in the field, and Votorantim Energia for logistic support at Ourinhos Reservoir. Thanks are due to two anonymous reviewers and L. C. Gomes for their suggestions on earlier versions of the manuscript.

\section{Literature Cited}

Agostinho A. A., L. C. Gomes, S. Veríssimo \& E. K. Okada. 2004. Flood regime, dam regulation and fish in the Upper Paraná River: effects on assemblage attributes, reproduction and recruitment. Reviews in Fish Biology and Fisheries, 14: 11-19.

Agostinho, A. A., L. C. Gomes \& F. M. Pelicice. 2007a. Ecologia e Manejo de Recursos Pesqueiros em Reservatórios do Brasil. Maringá, Eduem, 501p.

Agostinho A. A., E. E. Marques, C. S. Agostinho, D. A. Almeida, R. J. Oliveira \& J. R. B. Melo. 2007b. Fish ladder of Lajeado Dam: migrations on one-way routes? Neotropical Ichthyology, 5: 121130 .

Agostinho C. S., A. A. Agostinho, F. M. Pelicice, D. A. Almeida \& E. E. Marques. 2007c. Selectivity of fish ladders: a bottleneck in Neotropical fish movement. Neotropical Ichthyology, 5: 205-213. Agostinho, C. S., F. M. Pelicice, Marques E. E., A. B. Soares \& D. A. A. Almeida. 2011. All that goes up must come down? Absence of downstream passage through a fish ladder in a large Amazonian river. Hydrobiologia, 675: 1-12.

ANEEL. 2012. http://www.aneel.gov.br/. Accessed in January 2012.

Antonio, R. R., A. A. Agostinho, F. M. Pelicice, D. Bailly, E. K. Okada \& J. H. P. Dias. 2007. Blockage of migration routes by dam construction: can migratory fish find alternatives routes? Neotropical Ichthyology, 5: 177-184.

Araújo-Lima, C. A. R. M., A. A. Agostinho \& N. Fabré. 1995. Trophic aspects of fish communities in Brazilian rivers and reservoirs. Pp. 105-136. In: Tundisi J. G., C. E. M. Bicudo \& T. M. Tundisi (Eds.). Limnology in Brazil. Rio de Janeiro, ABC/ SBL. 384p.

Arcifa, M. S., O. Froehlich \& T. G. Northcote. 1988. Distribution and feeding ecology of fishes in a tropical Brazilian reservoir. Memoria de la Sociedad de Ciencias Naturales La Salle, 48, sup. 2: 301-326.

Arcifa, M. S. \& A. J. Meschiatti. 1993. Distribution and feeding ecology of fishes in a Brazilian reservoir: Lake Monte Alegre. Interciencia, 18: 302-313.

Arcifa, M. S. \& T. G. Northcote. 1997. Need for holistic approaches in food web experiments and biomanipulation in tropical lakes: A Brazilian reservoir experience. Verhandlungen Internationale Vereinigung Limnologie, 26: 661-665.

Bennemann, S. T., O. A. Shibatta \& J. C. Garavello. 2000. Peixes do rio Tibagi: uma abordagem ecológica. Londrina, Ed. UEL, 62p.

Brandão, H., A. P. Vidotto-Magnoni, I. P. Ramos \& E. D. Carvalho. 2009. Assessment of the ichthyofauna in stretches under the influence of Salto Grande Reservoir (Middle Paranapanema River, SP/PR, Brazil). Acta Limnologica Brasiliensia, 21: 451463.

Castro R. M. C., L. Casatti, H. F. Santos, K. M. Ferreira, A. C. Ribeiro, R. C. Benine, G. Z. P. Dardis, A. L. A. Melo, R. Stopiglia \& T. X. Abreu. 2003. Estrutura e composição da ictiofauna de riachos do Rio Paranapanema, Sudeste e Sul do Brasil. Biota Neotropica, 3: 1-31. 
Dias, J. H. P. 2003. Distribuição espacial e temporal da ictiofauna do trecho médio do rio Paranapanema e suas relações com as características morfológicas e limnológicas dos compartimentos da bacia. Unpublished Ph.D. Dissertation, Universidade Federal de São Carlos, São Carlos, 127p.

Dias, J. H. P. \& J. C. Garavello. 1998. Ecological studies on the fish community of Salto Grande Reservoir, Paranapanema River Basin, São Paulo, Brazil. Verhandlungen Internationale Vereinigung Limnologie, 26: 2228-2231.

Duke Energy. 2008. Peixes do Rio Paranapanema. São Paulo, Editora Horizonte. $120 \mathrm{p}$.

Esguícero, A. L. H. \& M. S. Arcifa. 2010. Fragmentation of a Neotropical migratory fish population by a century-old dam. Hydrobiologia, 638: 41-53.

Hoffmann, A. C., M. L. Orsi \& O. A. Shibatta. 2005. Diversidade de peixes da UHE Escola Engenharia Mackenzie (Rio Paranapanema), bacia do alto rio Paraná, Brasil, e a importância dos grandes tributários para sua manutenção. Iheringia, Série Zoologia, 95: 319-325.

Makrakis, S., M. C. Makrakis, R. L. Wagner, J. H. P. Dias \& L. C. Gomes. 2007. Utilization of the fish ladder at the Engenheiro Sergio Motta Dam, Brazil, by long distance migrating potamodromous species. Neotropical Ichthyology, 5: 197-204. Margalef, R. 1974. Ecologia. Ediciones Omega, Barcelona, 951p.

Meschiatti, A. J. \& M. S. Arcifa 2002. Early life stages of fish and the relationships with zooplankton in a tropical Brazilian reservoir: Lake Monte Alegre. Brazilian Journal of Biology, 62: 41-50.

Pelicice F. M. \& A. A. Agostinho. 2008. Fish passage facilities as ecological traps in large neotropical rivers. Conservation Biology, 22: 180-188.
Pompeu, P. S., A. A. Agostinho \& F. M. Pelicice. 2012. Existing and future challenges: the concept of successful fish passage in South America. River Research and Applications, 28: 504-512.

Reis, R. E., S. O. Kullander \& C. J. Ferraris. 2003. Check List of the Freshwater Fishes of South and Central America. Porto Alegre, EDIPUCRS, 729p.

Sanches, P. V., K. Nakatani, A. Bialetzki, G. Baumgartner, L. C. Gomes \& E. A. Luiz. 2006. Flow regulation by dams affecting ichthyoplankton: the case of the Porto Primavera dam, Paraná River, Brazil. River Research and Applications, 22: 555-565.

Souto, A. C. 2011. Partilha de recursos alimentares nas assembléias de peixes do reservatório de Salto Grande (Médio rio Paranapanema SP/PR, Brasil). Unpublished Ms.C Dissertation, Universidade Estadual Paulista, Botucatu, 50p.

Vianna, N. C. 2008. Deplecionamento induzido do reservatório de Salto Grande (Rio Paranapanema, SP/PR): influência sobre a ictiofauna de lagoas marginais. Unpublished Ph.D. Dissertation, Universidade Estadual Paulista, Botucatu, 106p.

Vianna, N. C. \& M. G. Nogueira. 2008. Ichthyoplankton and limnological factors in the Cinzas River - an alternative spawning site for fishes in the middle Paranapanema River basin, Brazil. Acta Limnologica Brasiliensia, 20: 139-151.

Ziesler, R. \& G. D. Ardizzone. 1979. The inland waters of Latin America. Copescal Technical Paper No. 1. Food and Agriculture Organization of the United Nations (FAO), Roma, 171p.

Submitted January 25, 2012 Accepted October 15, 2012 